Article

\title{
Simulation and Prediction of Climate Variability and Assessment of the Response of Water Resources in a Typical Watershed in China
}

\author{
Hua Jin ${ }^{1}$ * , Qiao Zhu ${ }^{2}$, Xuehua Zhao ${ }^{1}$ and Yongbo Zhang ${ }^{1}$ \\ 1 College of Water Resources Science and Engineering, Taiyuan University of Technology, Taiyuan 030024, \\ China; zhaoxuehua@tyut.edu.cn (X.Z.); zhangyongbo@tyut.edu.cn (Y.Z.) \\ 2 Geophysical Exploration Brigade of Hubei Geological Bureau, Wuhan 430056, China; zhuqiao86@163.com \\ * Correspondence: jinhua@tyut.edu.cn; Tel.: +86-351-658-5343
}

Academic Editor: Marco Franchini

Received: 4 July 2016; Accepted: 26 October 2016; Published: 28 October 2016

\begin{abstract}
The assessment of water resource responses to climate change is required in water resource planning and management, protecting environmental quality, and managing watersheds. This study modeled surface runoff and baseflow responses to variations in precipitation $(0 \%, \pm 10 \%$, and $\pm 20 \%)$ and temperature $\left(0^{\circ} \mathrm{C}, \pm 1{ }^{\circ} \mathrm{C}\right.$, and $\left.\pm 2{ }^{\circ} \mathrm{C}\right)$ in 25 types of scenarios in the Lanhe Watershed $\left(1140 \mathrm{~km}^{2}\right)$, which possesses the typical hydrological and meteorological characteristics of the Loess Plateau in China. The study is based on the Soil and Water Assessment Tool (SWAT), which was calibrated and validated using the coefficient of determination $\left(\mathrm{R}^{2}\right)$, Nash-Suttcliffe (Ens), and Percent bias (PBIAS), using the observed streamflow of Shangjingyou Station, a unique gauging station in the study area. The model was calibrated with daily streamflow, from 1967 to 1996, and then validated from 1997 to 2011. $\mathrm{R}^{2}$, Ens, and PBIAS were 0.95 and $0.84,0.78$ and 0.72 , and $0.6 \%$ and $-9.1 \%$ in annual and monthly calibration periods, 0.90 and $0.78,0.74$ and 0.67 , and $22.1 \%$ and $18.8 \%$ in annual and monthly validation periods, and the overall performance ratings was "satisfactory". The assessment indicates that surface runoff is likely to be more affected than baseflow when altering temperatures and precipitation, and the noticeable changes of surface and baseflow are from June to September and October to November, respectively. Results also indicate that surface runoff and baseflow are very sensitive to the projected reduction in temperature, rather than to an increase of temperature, while precipitation is a constant. In turn, when the temperature is a constant, the surface runoff is sensitive to the projected increase in precipitation and the baseflow is sensitive to the decrease in precipitation.
\end{abstract}

Keywords: climate variability and change; surface runoff; baseflow; Lanhe Watershed; SWAT model

\section{Introduction}

The impacts of climate change on hydrology cycling and water resource quantity and timing have attracted more and more researchers to the fields of hydrology, geohydrology, ecology, et al. [1-3]. Anticipating changes in water resources related to hydrological processes is particularly important for regions where water resources are scarce owing to population growth and economic prosperity [4-8], especially in regions of the upper and middle reaches of the Yellow River, where the shortage of water resources has resulted in a series of ecological and environmental issues, as well as the problem of social economy [9-14].

Most studies indicate that hydrological processes may be sensitive to changes in precipitation and temperature [15-18], which are the main climate variables. Changes of temperature have a strong impact on evapotranspiration, soil moisture, and the thermal circulation of the atmosphere, and, thus, on surface runoff and baseflow, as well as on crop production. The variability of precipitation directly 
changes the water resources of surface runoff, baseflow, and interflow, which then cause floods and droughts, which result from issues of social economy and the ecosystem and affect the sustainable use of water resources [19-22]. Thus, temperature and precipitation are usually chosen as the main influencing factors in order to design climate variability scenarios [23,24]. The climate change scenarios in most research are often projected using global or regional climate model experiments, of which a major limitation is large-scale resolution [25]. In this study, based on the annual and monthly mean values ( $\mathrm{P}$ for precipitation, $\mathrm{T}$ for temperature), the arbitrary values of precipitation $(\mathrm{P}, \mathrm{P} \pm 10 \%$, and $\mathrm{P} \pm 20 \%$ ) and temperature ( $\mathrm{T}, \mathrm{T} \pm 1{ }^{\circ} \mathrm{C}$, and $\mathrm{T} \pm 2{ }^{\circ} \mathrm{C}$ ) were selected to simulate climate variability in order to bracket the range of possible precipitations and temperatures.

The main target of this paper is study of the water resources of the Lanhe Watershed under climate variability using the Soil and Water Assessment Tool (SWAT) model, which performs well all around the world, in different climatic situations, for solving hydrological environmental problems [26-28]. The Lanhe Watershed is a typical watershed of the Loess Plateau, where the climate presents semi-arid characteristics, with most precipitation falling from June to September [29]. Precipitation stations and the stream gauge station in the study area can offer long-term continuous data sets, from 1967 to 2011, including daily, monthly, and annual precipitation and discharge data as a basis. In this paper, the first aim is to calibrate and validate the SWAT model using the observed discharge from gauging stations. The second aim is to apply the model by inspecting the sensitivity of surface runoff and baseflow occurring with the change of temperature and precipitation, while noting the better performance of the model.

\section{Study Area}

The Lanhe Watershed, located in the upper and middle reaches of the Yellow River, is a representative region of the Loess Plateau. The Lanhe River is a secondary tributary of the Yellow River, and lies in the middle of Shanxi Province, China (Figure 1). The study area is about $1140 \mathrm{~km}^{2}$, the total river length is $57.6 \mathrm{~km}$, and the mean of the river slope is $4.05 \%$. It has semi-arid and arid climate characteristics, with less precipitation in winter and spring, and more rain in summer and autumn, the precipitation of which accounts for more than $60 \%$ of the annual precipitation $[30,31]$. The weather is affected by local and regional climatic influences, with northwestern winds in late autumn, winter, and spring, and southeastern winds in summer. The annual precipitation is $477.3 \mathrm{~mm}$, the annual temperature is $8.8^{\circ} \mathrm{C}$, and the annual evapotranspiration is $1310.7 \mathrm{~mm}$. In the Lanhe Watershed, about $80 \%$ of the annual precipitation falls from June to September (the flood season), and is usually concentrated in several rain events during July and August [32]. Streamflow in the flood season accounts for $60 \%-80 \%$ of the annual total streamflow, and runoff generation is dominated by surface runoff, produced by the infiltration-excess mechanism; baseflow is commonly from $0.1 \mathrm{~m}^{3} / \mathrm{s}$ to $0.3 \mathrm{~m}^{3} / \mathrm{s}$ [33]. The location of the Lanhe Watershed is shown in Figure 1. 


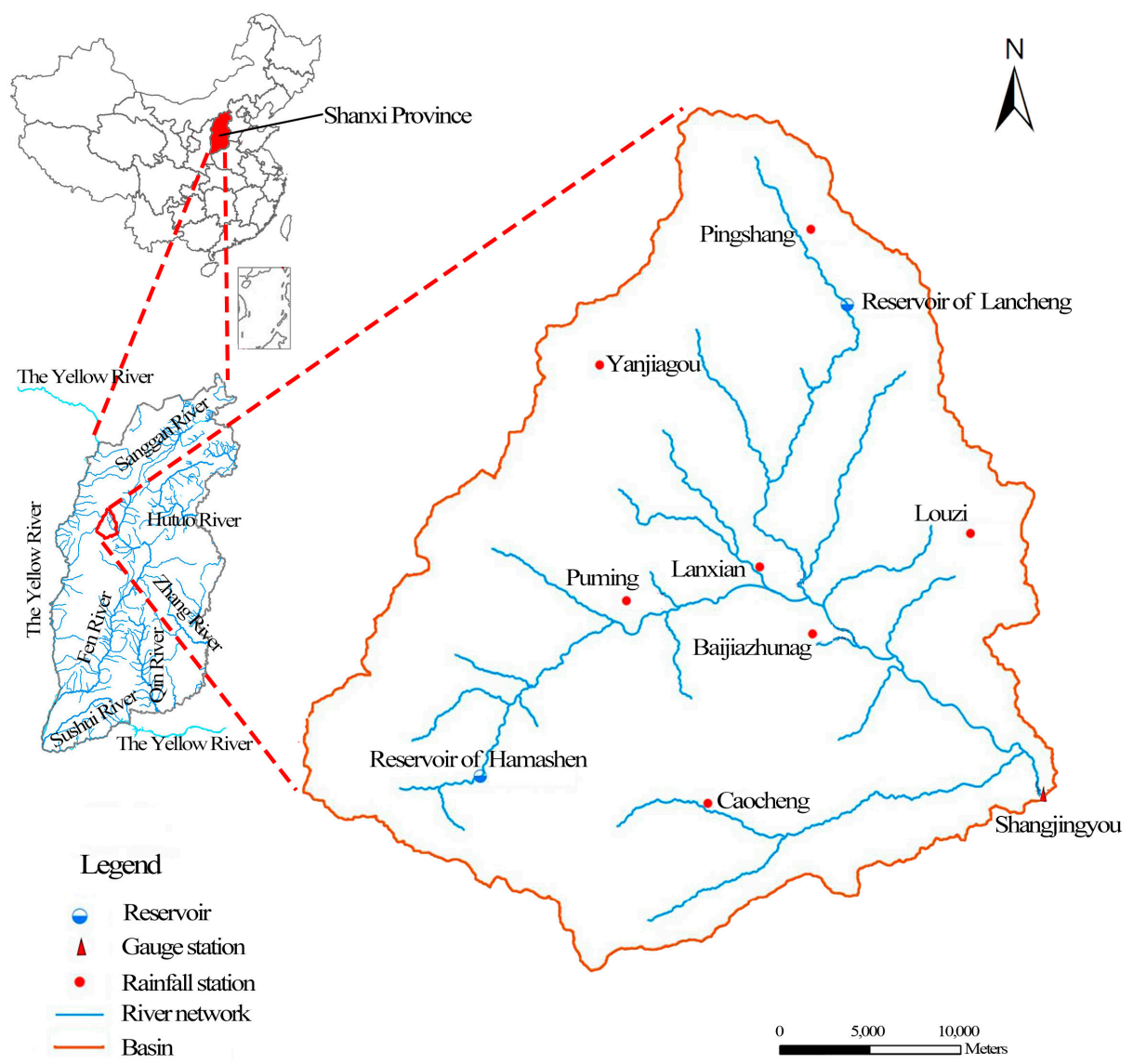

Figure 1. Location, rainfall, and gauging stations of the Lanhe Watershed.

\section{Methodology and Materials}

\subsection{SWAT (Soil and Water Assessment Tool) Model}

SWAT was developed by the United States Department of Agricultural Research Service and Texas A\&M University laboratories [34]. It is a physically based, spatially distributed, continuous simulation watershed model, and it has been utilized to simulate the hydrological processes of interception, infiltration, surface runoff, evapotranspiration, percolation, lateral flow, and groundwater recharge, based on the water balance equation at a daily time step [35]. The SWAT model also provides several software tools, which include the pre- and post-processing software, automatic and manual calibration procedures, and an ArcGIS SWAT interface, as well as abundant theoretical and technical documentation, which consist of theoretical documentation, a user's manual and guide, a developer's manual, etc. [36-38]. Most of the software and documentation are conveniently and freely obtainable from [39]. Thus, it has been widely used around the world for hydrological processes and soil movement, the assessment of water resources and water quality, and in the movement and transformation of nutrients (such as nitrogen, phosphorus) and pesticides [40,41]. In recent years, the model has been increasingly applied in evaluating climate impacts on water resources at the basin scale, for small to large catchments [42-47].

In the SWAT model, both the Soil Conservation Service (SCS) curve number and the Green and Ampt infiltration method are developed to estimate surface runoff, and the three potential evapotranspiration (PET) methods, the Penman-Monteith method, the Priestley-Taylor method, and the Hargreaves method, are used to simulate PET [48,49]. In addition, the SWAT model subdivides groundwater systems as shallow or deep aquifers. The shallow aquifer is an unconfined aquifer, returning groundwater to the streams, and a deep aquifer is a confined aquifer, contributing flow 
to the outside of the subbasin [35]. The SCS curve number and the Penman-Monteith method were selected in this paper to calculate surface runoff and PET.

\subsection{Model Setup}

\subsubsection{Data Collection and Analysis}

Digital Elevation Model (DEM) data using a $30 \mathrm{~m}$ resolution were downloaded from the Computer Network Information Center of the Chinese Academy of Sciences. It was used to delineate the subwatershed and stream network, as well as to derive the sub-watershed parameters of the area, length, width, mean slope, and average elevation.

For both land use and soil data, the resolution was $1000 \mathrm{~m}$, and was acquired from the Environmental and Ecological Data Center of the Chinese Academy of Sciences. The main land use types were evergreen coniferous forest, deciduous broad-leaved forest, shrubwood, grassland, and farmland; the main soil types were calcareous cambisol, eutric cambisol, calcareous fluvisol, haplustalf, calcareous alfisol, and calcareous rhogosol.

The meteorological data of the Lanhe Watershed were obtained from the China Meteorological Data Sharing Service System. The daily climate data included maximum and minimum temperatures, wind speed, and relative humidity, as well as daily sunshine duration, from 1967 to 2011 . The mean annual values of temperature, evapotranspiration, wind speed, relative humidity, and sunshine duration were $8.8^{\circ} \mathrm{C}, 1310.7 \mathrm{~mm}, 2.1 \mathrm{~m} / \mathrm{s}, 59 \%$, and $2542.3 \mathrm{~h}$, respectively.

The precipitation and streamflow data were obtained from the Hydrology and Water Resource Survey Administration of Shanxi, China, and contained daily precipitation and runoff. There are seven precipitation stations (Pingshang, 21350; Puming, 21250; Yanjiagou, 21300; Baijiazhuang, 21450; Louzi, 21500; Caocheng, 21600; and Shangjingyou, 21650), which are evenly distributed in the study area, and one stream gauge station (Shangjingyou), which is the outlet of the Lanhe catchment. The longest time span of meteorological and hydrological data (45-year period, from 1967 to 2011) was used for the research. The average annual precipitation was $477.3 \mathrm{~mm}$, with the maximum and minimum rainfalls being $816.9 \mathrm{~mm}$ and $266.5 \mathrm{~mm}$; the mean annual flow was estimated to be about $43.41 \mathrm{~mm}^{3}$ /year, $38.1 \mathrm{~mm}$ for runoff depth, and 0.07 for the mean runoff coefficient; the maximum and minimum temperatures were $10.4{ }^{\circ} \mathrm{C}$ and $7.5^{\circ} \mathrm{C}$, respectively.

\subsubsection{Characterization and Delineation of Hydrological Response Units}

In this study, model setup and parameterization were done using the ArcSWAT interface. First, the Lanhe Watershed was divided into 25 subbasins, decided by a threshold area of 1000 ha (Figure 2) with DEM data of $30 \mathrm{~m}$ in resolution. Then, all subbasins were fully divided into 81 hydrologic response units (HRUs), based on a combination of land use, soil class (type), and land slope, representing over $15 \%$ threshold of land use, soil, and slope, respectively.

\subsubsection{Model Calibration and Validation}

The determination of the most sensitive parameters is the key, and first step, for model calibration and validation at the watershed scale [50]. The sensitivity analysis can classify the sensitive parameters, from most sensitive to least sensitive for the input parameters. Within the model, a number of parameters are specified in order to identify the spatial units of the subbasins, and the hydrologic response units (HRUs) may be assessed from available data. Latin Hypercube One-factor-At-a-Time (LH-OAT) was used for a preliminary sensitivity analysis of the parameters [51]. The Shuffle Complex Evolution Method (SCEM-UA), proposed by Song et al. [52], was then employed for a formal calibration using the streamflow data of Shangjingyou Gauge Station, from 1967 to 2011. The coefficient of determination $\left(\mathrm{R}^{2}\right)$, Nash-Suttcliffe (Ens), and Percent bias (PBIAS) were used to assess model performance. 
The coefficient of determination $\left(\mathrm{R}^{2}\right)$, Nash-Suttcliffe (Ens), and Percent bias (PBIAS), defined by Equations (1)-(3), were done using a statistics performance for the model $[53,54] . R^{2}$ commonly describes the degree of agreement between simulated values and measured values. A value of 1.0 indicates a perfect prediction, and a value of 0.0 suggests an unsatisfactory prediction. In general, when a value is greater than 0.5 it is considered to be acceptable [55].

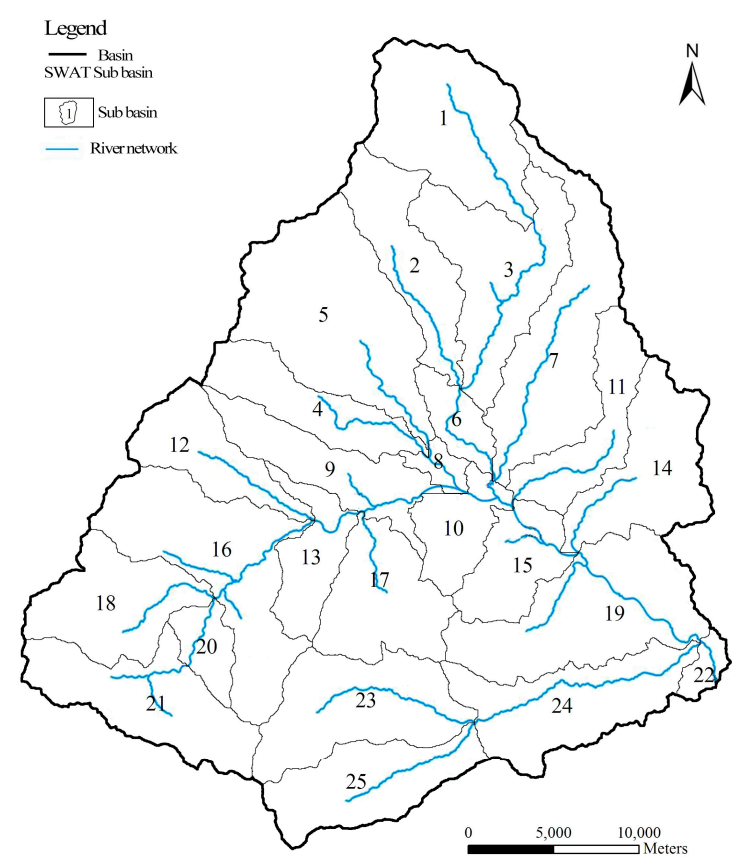

Figure 2. Map of the subbasins.

Ens indicates how well the plot of observed versus simulated data fits the 1:1 line. A value of $0.75<$ Ens $\leq 1.00$ is very good, $0.65<$ Ens $\leq 0.75$ is good, $0.5<$ Ens $\leq 0.65$ is satisfactory, and Ens $\leq 0.5$ is unsatisfactory [56].

PBIAS indicates the sum of differences between measured and simulated values over the sum of measured value. A PBIAS $\leq 10 \%$ is very good, $10 \%<$ PBIAS $\leq 15 \%$ is good, $15 \%<$ PBIAS $\leq 25 \%$ is satisfactory, and PBIAS $>25 \%$ is unsatisfactory $[57,58]$.

$$
\begin{gathered}
\mathrm{R}^{2}=\frac{\left[\sum_{i=1}^{n}\left(Q_{i}^{\text {obs }}-Q_{i}^{a v g}\right)\left(P_{i}^{\text {sim }}-P_{i}^{a v g}\right)\right]^{2}}{\sum_{i=1}^{n}\left(Q_{i}^{\text {obs }}-Q_{i}^{a v g}\right)^{2} \sum_{i=1}^{n}\left(P_{i}^{\text {sim }}-P_{i}^{a v g}\right)^{2}} \\
\text { Ens }=1-\frac{\sum_{\mathrm{i}=1}^{\mathrm{n}}\left(\mathrm{Q}_{\mathrm{i}}^{\text {obs }}-\mathrm{P}_{\mathrm{i}}^{\text {sim }}\right)^{2}}{\sum_{\mathrm{i}=1}^{\mathrm{n}}\left(\mathrm{Q}_{\mathrm{i}}^{\text {obs }}-\mathrm{Q}_{\mathrm{i}}^{\mathrm{avg}}\right)^{2}} \\
\text { PBIAS }=\frac{\sum_{i=1}^{n}\left(Q_{i}^{\text {obs }}-P_{i}^{\text {sim }}\right)}{\sum_{i=1}^{n} Q_{i}^{\text {obs }}} \times 100
\end{gathered}
$$

where: $n$ is the total number of observations. $Q_{i}{ }^{o b s}$ is the observed data; $Q_{i}{ }^{a v g}$ is the average of the observed data. $P_{i}^{\text {sim }}$ is the simulated data; $P_{i}^{\text {avg }}$ is the average of the simulated data. 


\subsection{Scenarios of Climate Change}

Precipitation and temperature variables significantly affect the hydrological process; thus, in this study, they were selected in order to design climate change scenarios with the arbitrary scenarios method, based on the tendencies of temperature and precipitation in the study area.

\subsubsection{Design of the Climate Scenarios}

Historical temperature and precipitation data (from 1967 to 2011) were collected in order to investigate climatic change and the hydrometeorological characteristics of the study area for the design of climate change scenarios. The Mann-Kendall test (M-K test) assessed the trends and abrupt changes in a time series [59], and linear trend analyses were used for temperature analyses [60]; and the five-year moving average and accumulating anomalies were applied to the precipitation analysis.

UF and UB are standardized statistical series which can be written as Equations (4) and (5) in the $\mathrm{M}-\mathrm{K}$ test [61]. When the UF curve and the UB curve intersect in the confidence zone, the cross point indicates that it is an abrupt point [61].

$$
\begin{gathered}
\mathrm{UF}(k)=\frac{\left[d_{k}-E\left(d_{k}\right)\right]}{\sqrt{\operatorname{var}\left(d_{k}\right)}},(k=2,3, \ldots, \mathrm{n}) \\
\mathrm{UB}(k)=-\frac{\left[d_{k}-E\left(d_{k}\right)\right]}{\sqrt{\operatorname{var}\left(d_{k}\right)}},(k=2,3, \ldots, \mathrm{n})
\end{gathered}
$$

Figures 3 and 4 show temperature tendency and change, and Figure 5 demonstrates precipitation tendency and change. According to Figures 3 and 4, the mean annual temperature presented a wave of increasing tendency, which experienced a sudden change, which was the intersection point between UF and UB curves in 1990. The annual average temperature, maximum temperature, and minimum temperature were $8.8^{\circ} \mathrm{C}, 10.4{ }^{\circ} \mathrm{C}$, and $7.5^{\circ} \mathrm{C}$, and the rate was $0.29{ }^{\circ} \mathrm{C}$ every 10 years. From Figure 5, the precipitation for a five-year moving average anomaly showed a decreasing tendency. In the periods of 1967-1972, 1979-1984, and 1993-2006, precipitation presented a decreasing tendency. However, in 1973-1978, 1985-1992, and 2007-2011, the precipitation indicated an increasing tendency. The annual average, maximum, and minimum precipitations were $477.3 \mathrm{~mm}, 816.9 \mathrm{~mm}$ (1967), and $266.5 \mathrm{~mm}$ (1972).

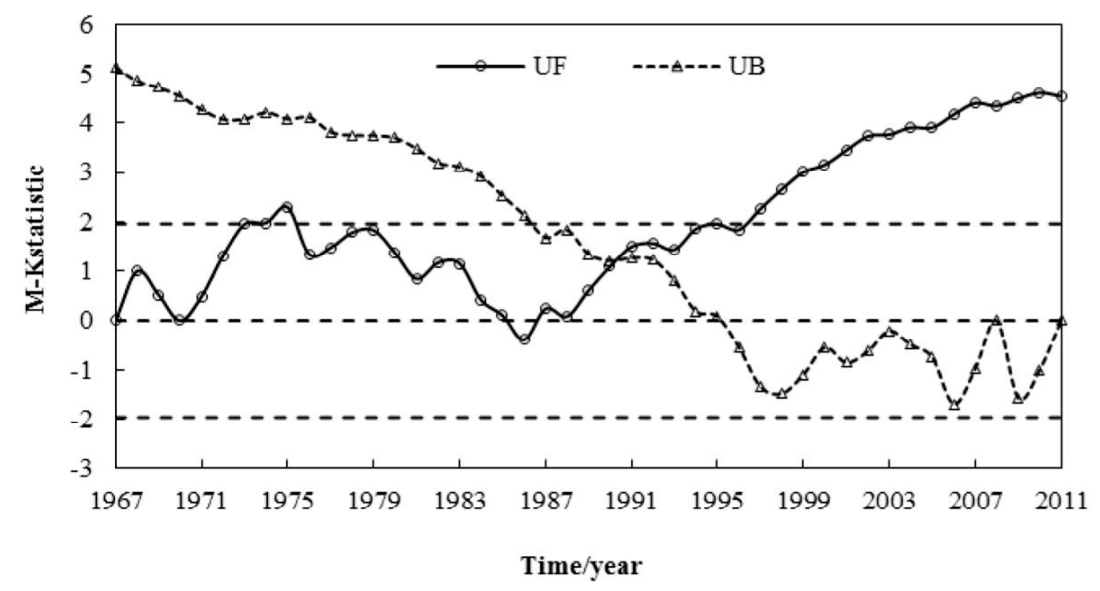

Figure 3. The $\mathrm{M}-\mathrm{K}$ test for average annual temperature in the Lanhe Watershed.

From previous investigations, average annual temperatures will increase from $1.7^{\circ} \mathrm{C}$ to $2.3^{\circ} \mathrm{C}$, and the average annual precipitation will increase from $5 \%$ to $23 \%$, according to a report on comprehensive environmental evolution assessment in the west of China. Meanwhile, considering the 
hydrometeorological characteristics of the study area, generally, the annual precipitation varied from $-20 \%$ to $+20 \%$, and the annual mean temperature varied from $-2{ }^{\circ} \mathrm{C}$ to $2{ }^{\circ} \mathrm{C}$.

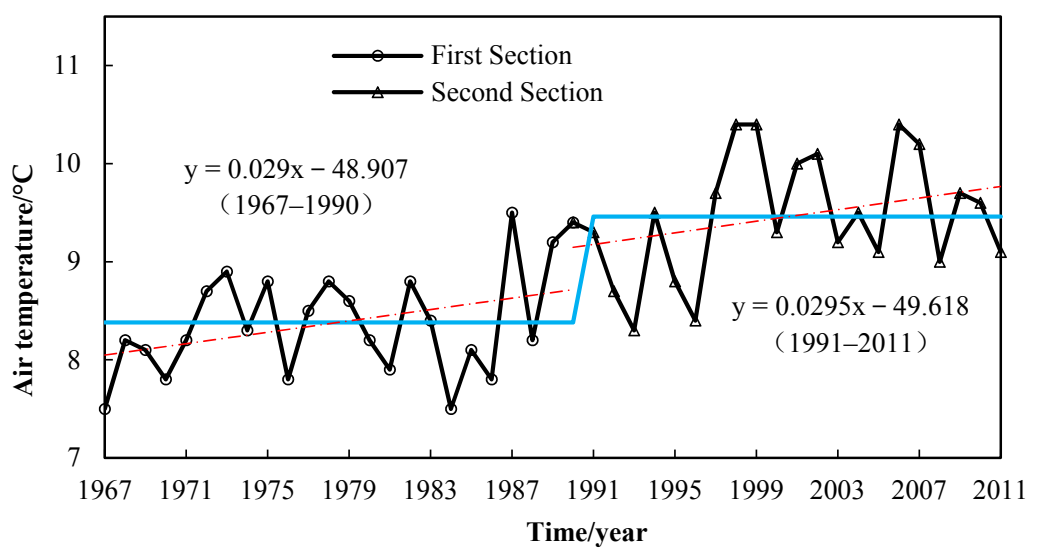

Figure 4. Average annual temperature and tendencies in the Lanhe Watershed.

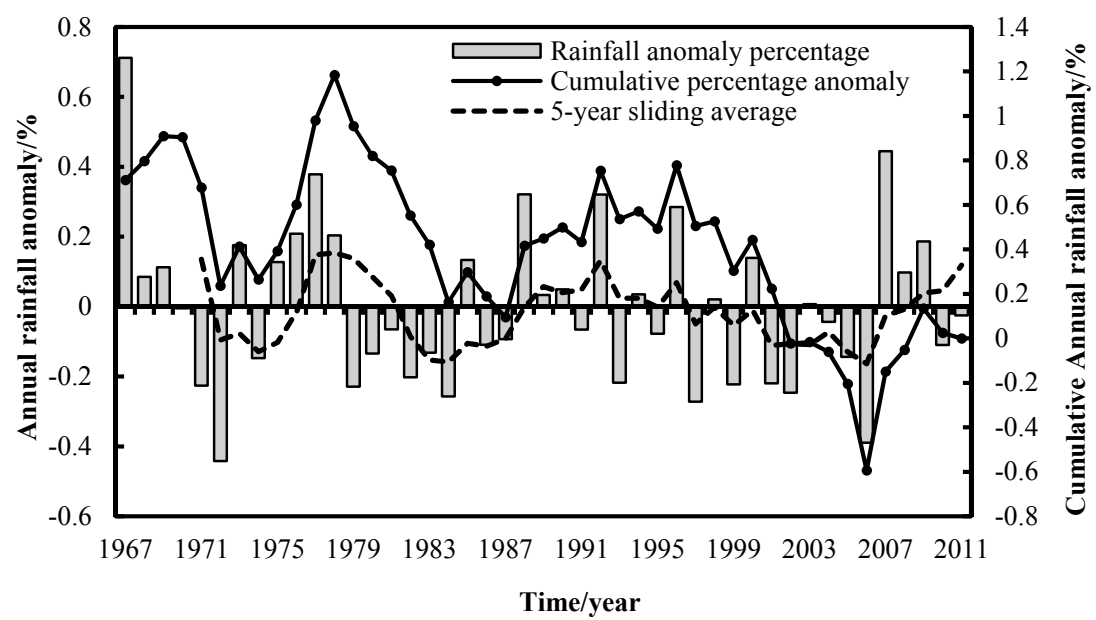

Figure 5. The annual average precipitation departure and accumulated anomalies of the Lanhe Watershed.

As a result, climate scenarios were formulated by changing the temperatures and precipitations of the annual mean. Temperature was constructed by altering the annual average temperature $\left(8.8^{\circ} \mathrm{C}\right)$ in steps of $1{ }^{\circ} \mathrm{C}$ for $\pm 2{ }^{\circ} \mathrm{C}$ (such as $+10.8^{\circ} \mathrm{C},+9.8^{\circ} \mathrm{C}, 8.8^{\circ} \mathrm{C}, 7.8^{\circ} \mathrm{C}$, and $6.8^{\circ} \mathrm{C}$ ), and the annual mean precipitation $(477.3 \mathrm{~mm}$ ) changing by steps of $10 \%$ for $\pm 20 \%$ (such as $572.76 \mathrm{~mm}, 525.03 \mathrm{~mm}, 477.3 \mathrm{~mm}$, $429.57 \mathrm{~mm}$, and $381.84 \mathrm{~mm}$ ). Twenty-five scenarios of climate change were formulated using the arbitrary scenario method for SWAT model simulation (see Table 1). The base scenario is S33, P being the annual average precipitation and $\mathrm{T}$ being the annual average temperature.

Table 1. Climate scenarios designed for the Lanhe Watershed.

\begin{tabular}{cccccc}
\hline \multirow{2}{*}{ Temperature } & \multicolumn{5}{c}{ Precipitation (P) } \\
\cline { 2 - 6 } & $\mathbf{P} \times \mathbf{( 1 - 2 0 \% )}$ & $\mathbf{P} \times \mathbf{( 1 - 1 0 \% )}$ & $\mathbf{P}$ & $\mathbf{P} \times \mathbf{( 1 + 1 0 \% )}$ & $\mathbf{P} \times \mathbf{( 1 + 2 0 \% )}$ \\
\hline $\mathrm{T}-2{ }^{\circ} \mathrm{C}$ & $\mathrm{S} 11$ & $\mathrm{~S} 12$ & $\mathrm{~S} 13$ & $\mathrm{~S} 14$ & $\mathrm{~S} 15$ \\
$\mathrm{~T}-1{ }^{\circ} \mathrm{C}$ & $\mathrm{S} 21$ & $\mathrm{~S} 22$ & $\mathrm{~S} 23$ & $\mathrm{~S} 24$ & $\mathrm{~S} 25$ \\
$\mathrm{~T}$ & $\mathrm{~S} 31$ & $\mathrm{~S} 32$ & $\mathrm{~S} 33$ & $\mathrm{~S} 34$ & $\mathrm{~S} 35$ \\
$\mathrm{~T}+1{ }^{\circ} \mathrm{C}$ & $\mathrm{S} 41$ & $\mathrm{~S} 42$ & $\mathrm{~S} 43$ & $\mathrm{~S} 44$ & $\mathrm{~S} 45$ \\
$\mathrm{~T}+2{ }^{\circ} \mathrm{C}$ & $\mathrm{S} 51$ & $\mathrm{~S} 52$ & $\mathrm{~S} 53$ & $\mathrm{~S} 54$ & $\mathrm{~S} 55$ \\
\hline
\end{tabular}




\subsubsection{Methods of Sensitivity Analysis}

For assessing climate change impacts on water resources, the rate of change of hydrological factors $\eta_{\Delta P, \Delta T}$, such as surface runoff and baseflow were defined using Equation (6).

$$
\eta_{\Delta P, \Delta T}=\frac{W_{P+\Delta P, T+\Delta T}-W_{P, T}}{W_{P, T}} \times 100
$$

$W_{P, T}$ is the value of the hydrological factors obtained for the surface runoff and baseflow using simulations of the SWAT model in the base scenarios. $W_{P+\Delta P, T+\Delta T}$ is the simulation result of surface runoff and baseflow, changing the annual average precipitation and temperature, by steps of $\Delta P(10 \%)$ for precipitation, or $\Delta T\left(1^{\circ} \mathrm{C}\right)$ for temperature.

\section{Results and Discussion}

\subsection{SWAT Model Calibration and Validation Results}

The results of model calibration and validation are shown in Table 2 and Figures 6 and 7. From the calibration and validation results of annual and monthly streamflows, $\mathrm{R}^{2}$ values are 0.95 and 0.84 , and 0.78 and 0.72 , and all results greater than 0.5 are considered to be acceptable; Ens values are 0.78 and 0.72 , and 0.74 and 0.67 , and the simulated results of the ratings are "very good" or "good"; PBIAS values are $0.6 \%$ and $-9.1 \%$, and $22.1 \%$ and $18.8 \%$, with a performance rating of "very good" for the calibration period, and a rating of "satisfactory" for the validation period. According to the evaluation criteria, the performance rating of the overall model simulated was "satisfactory". Figures 6 and 7 show that the measured and simulated annual and monthly streamflow were closely followed most of time. To sum up, the statistic values proved that the model performed well, not only on an annual scale but also on a monthly scale in the Lanhe Watershed, and that it can be used to predict water resources (surface runoff and baseflow).

Table 2. Performance statistics in the calibration and validation periods.

\begin{tabular}{ccccc}
\hline \multirow{2}{*}{ Test Statistic } & \multicolumn{2}{c}{ Calibration Period (1967-1996) } & \multicolumn{2}{c}{ Validation Period (1997-2011) } \\
\cline { 2 - 5 } & Annual Runoff & Monthly Runoff & Annual Runoff & Monthly Runoff \\
\hline $\mathrm{R}^{2}$ & 0.95 & 0.84 & 0.9 & 0.78 \\
Ens & 0.78 & 0.72 & 0.74 & 0.67 \\
PBIAS & $0.6 \%$ & $-9.1 \%$ & $22.1 \%$ & $18.8 \%$ \\
\hline
\end{tabular}

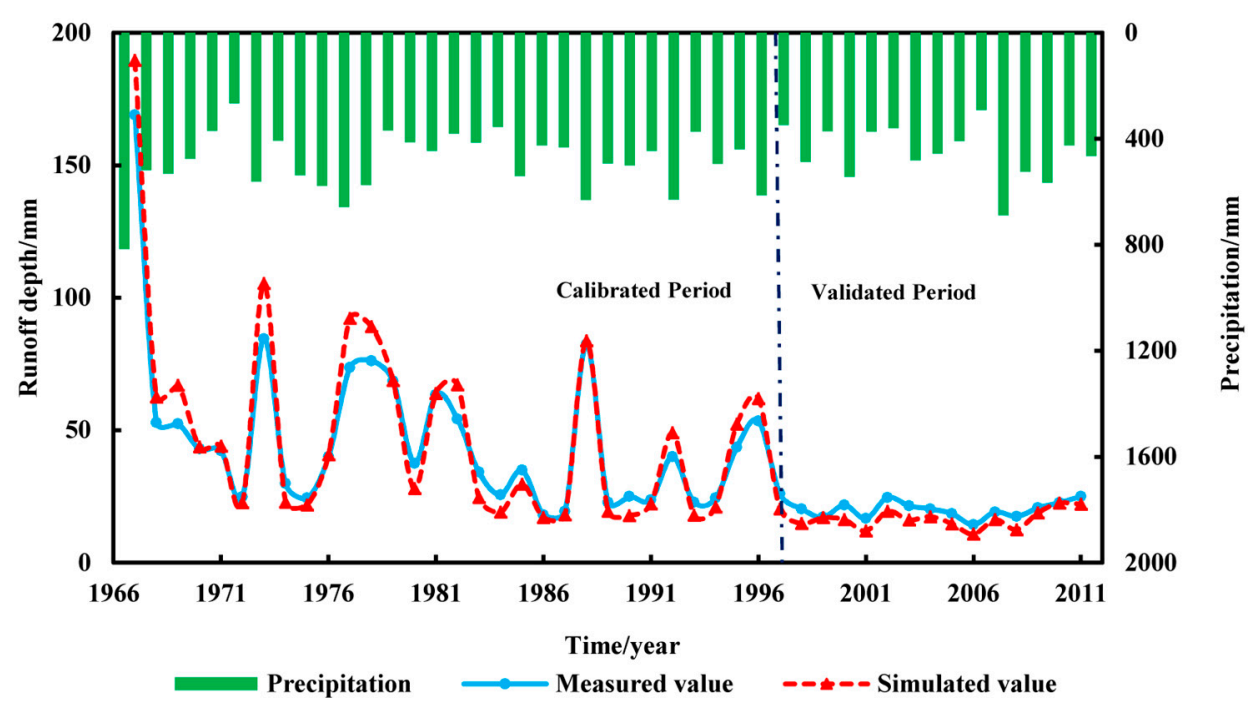

Figure 6. Observed and simulated annual streamflows at Shangjingyou Station. 


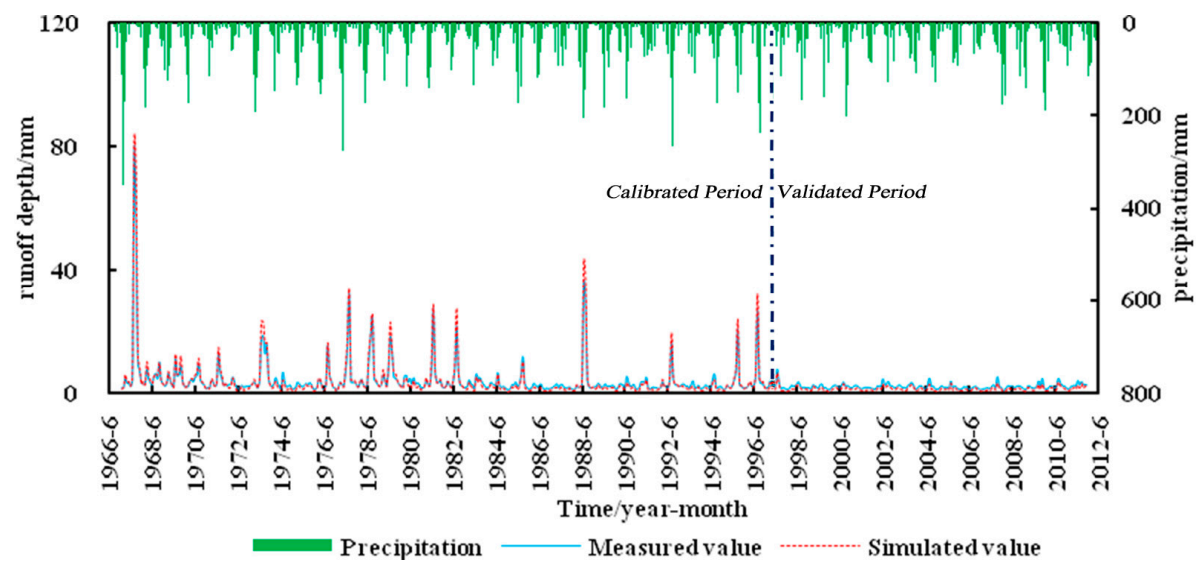

Figure 7. Observed and simulated monthly average streamflows at Shangingyou Station.

From the calibration and validation results, the optimal parameters of calibration and validation are listed in Table 3.

Table 3. Results of parameter calibration.

\begin{tabular}{ccccc}
\hline Parameters & File Suffixes & $\begin{array}{c}\text { Lower and } \\
\text { Upper Bound }\end{array}$ & $\begin{array}{c}\text { Calibrated } \\
\text { Value }\end{array}$ & Parameter Definition \\
\hline CN2 & ${ }^{*}$.mgt & $-25 \% \sim 25 \%$ & $18 \%$ & SCS runoff curve number \\
SOL_AWC & ${ }^{*}$.sol & $-25 \% \sim 25 \%$ & $20 \%$ & Available water capacity of soil layer \\
SLOPE & ${ }^{*}$.hru & $-25 \% \sim 25 \%$ & $24 \%$ & Average slope of subbasin \\
SOL_K & ${ }^{*}$.sol & $-25 \% \sim 25 \%$ & $18 \%$ & Saturated hydraulic conductivity \\
ESCO & ${ }^{*}$.hru & $0.00 \sim 1.00$ & 0.0067 & Soil evaporation compensation factor \\
SOL_Z & ${ }^{*}$.sol & $-25 \% \sim 25 \%$ & $24 \%$ & Depth from soil surface to bottom of layer \\
CANMX & ${ }^{*}$.hru & $0.00 \sim 10.00 \mathrm{~mm}$ & $0.023 \mathrm{~mm}$ & Maximum canopy storage \\
ALPHA_BF & ${ }^{*} \cdot \mathrm{gw}$ & $0.00 \sim 1.00$ & 0.97 & Base flow Alpha factor \\
\hline
\end{tabular}

\subsection{Sensitivity Analysis of Surface Runoff}

Table 4 shows the annual surface runoff obtained by the SWAT model with respect to the different temperatures and precipitations in each scenario. Figure 8 shows the rate of change relative to the base scenario (S33), of which the value is $43,411 \times 10^{3} \mathrm{~m}^{3}$.

Table 4. Annual surface runoff simulated in different scenarios.

\begin{tabular}{ccccccc}
\hline \multirow{2}{*}{ Surface Runoff } & \multirow{2}{*}{ Temperature } & \multicolumn{5}{c}{ Precipitation } \\
\cline { 3 - 7 } & & $\mathbf{- 2 0 \%}$ & $\mathbf{- 1 0 \%}$ & $\mathbf{0}$ & $\mathbf{1 0 \%}$ & $\mathbf{2 0 \%}$ \\
\hline & $\mathrm{T}-2{ }^{\circ} \mathrm{C}$ & $29,616.6$ & $38,671.6$ & $49,965.5$ & $62,769.5$ & $77,679.7$ \\
& $\mathrm{~T}-1{ }^{\circ} \mathrm{C}$ & $28,971.5$ & $36,066.1$ & $46,520.6$ & $58,070.9$ & $71,113.9$ \\
Volume $\left(10^{3} \mathrm{~m}^{3}\right)$ & $\mathrm{T}$ & $27,787.2$ & $34,830.7$ & $43,411.0$ & $53,998.2$ & $65,430.8$ \\
& $\mathrm{~T}+1{ }^{\circ} \mathrm{C}$ & $26,731.8$ & $32,937.0$ & $40,846.3$ & $51,174.6$ & $62,246.1$ \\
& $\mathrm{~T}+2{ }^{\circ} \mathrm{C}$ & $25,682.0$ & $32,228.5$ & $39,396.4$ & $48,188.3$ & $58,345.4$ \\
\hline
\end{tabular}

From Table 4 and Figure 8, both the precipitation and temperature variability changed the surface runoff, and the contribution of precipitation variability was far greater than that of temperature change. Comparing the surface flow of S33 with other scenarios, the smallest relative change of the surface flow decreased by $40.8 \%\left(17,729 \times 10^{3} \mathrm{~m}^{3}\right)$ when the precipitation decreased by $20 \%$ and the temperature increased by $2{ }^{\circ} \mathrm{C}$ (S51 scenario). The smallest relative change in the surface flow increased by $78.9 \%\left(34,268.7 \times 10^{3} \mathrm{~m}^{3}\right)$ when the precipitation increased by $20 \%$ and the temperature decreased by $2{ }^{\circ} \mathrm{C}(\mathrm{S} 15)$. 


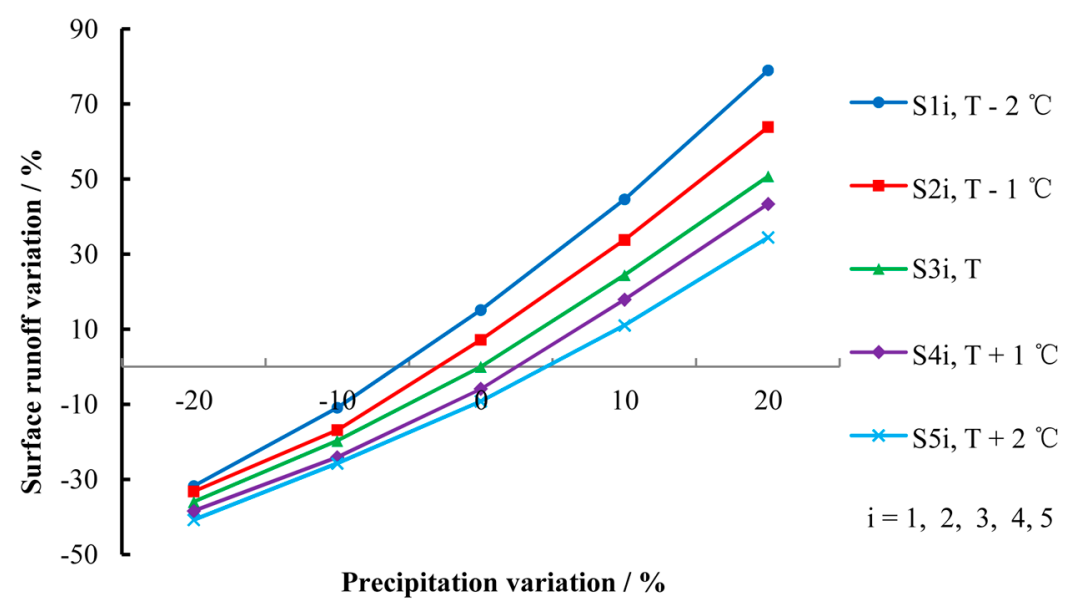

Figure 8. Rate of annual surface runoff change from base and other scenarios.

With respect to the same precipitation, the relative changes of surface runoff increased in the range of $1.5 \%\left(645 \times 10^{3} \mathrm{~m}^{3}\right.$, S11-S21) to $15.1 \%\left(6565.8 \times 10^{3} \mathrm{~m}^{3}\right.$, S15-S25), while the temperature decreased by $1{ }^{\circ} \mathrm{C}$, and the relative changes in surface runoff decreased in the range of $1.6 \%\left(708.4 \times 10^{3} \mathrm{~m}^{3}\right.$, S42-S52) to $9 \%\left(3900.7 \times 10^{3} \mathrm{~m}^{3}\right.$, S45-S55) while the temperature increased by $1{ }^{\circ} \mathrm{C}$, compared to the S33 scenario. The results show that the contribution of the reduction in temperature was greater than that of the increase in temperature for surface runoff.

With respect to situations where the same temperature is used, the relative changes of surface runoff increased in the range of $20.3 \%\left(8791.9 \times 10^{3} \mathrm{~m}^{3}\right.$, S54-S53) to $34.3 \%\left(14,910.2 \times 10^{3} \mathrm{~m}^{3}, \mathrm{~S} 15-\mathrm{S} 14\right)$, while the precipitation change increased by $10 \%$, and the relative changes of surface runoff decreased in the range of $14.3 \%\left(6205.2 \times 10^{3} \mathrm{~m}^{3}, \mathrm{~S} 42-\mathrm{S} 41\right)$ to $26.0 \%\left(11,293.9 \times 10^{3} \mathrm{~m}^{3}, \mathrm{~S} 13-\mathrm{S} 12\right)$ while the precipitation decreased by $10 \%$, relative to the S33 scenarios. The performance indicated that the contribution of increasing the relative precipitation variation rates was greater than that of the decrease for surface runoff.

In order to learn more about the changes in surface runoff and baseflow within a year, it is necessary to analyze periodic features of surface runoff and baseflow. In this paper, and based on flood and irrigation water management, the hydrological year was divided into four periods: the first period (the pre-crop period) from March to May, the second period (the flood season) from June to September, the third period (the post-flood season) from October to November, and the fourth period (the ice period) from December to February. Monthly surface flow changes were simulated under four scenarios: S31, $(1-20 \%) \mathrm{P}, \mathrm{T}$; S33, P, T; S51, $(1-20 \%) \mathrm{P}, \mathrm{T}+2{ }^{\circ} \mathrm{C}$; and S53, $\mathrm{P}, \mathrm{T}+2{ }^{\circ} \mathrm{C}$.

Figure 9 depicts that the surface runoff of S33 is greater than that of the S31, S51, and S53 scenarios, with a significant change in the average monthly surface water being in the flood season, with August showing the largest decrease, and a slight change in the ice period. The changes were in accordance with the monthly changes in precipitation. It should also be noted that the surface runoff reduction was greater under a $20 \%$ decrease in precipitation rather than a $2{ }^{\circ} \mathrm{C}$ increase in temperature for the flood season, and there were slight variations relative to other periods. 


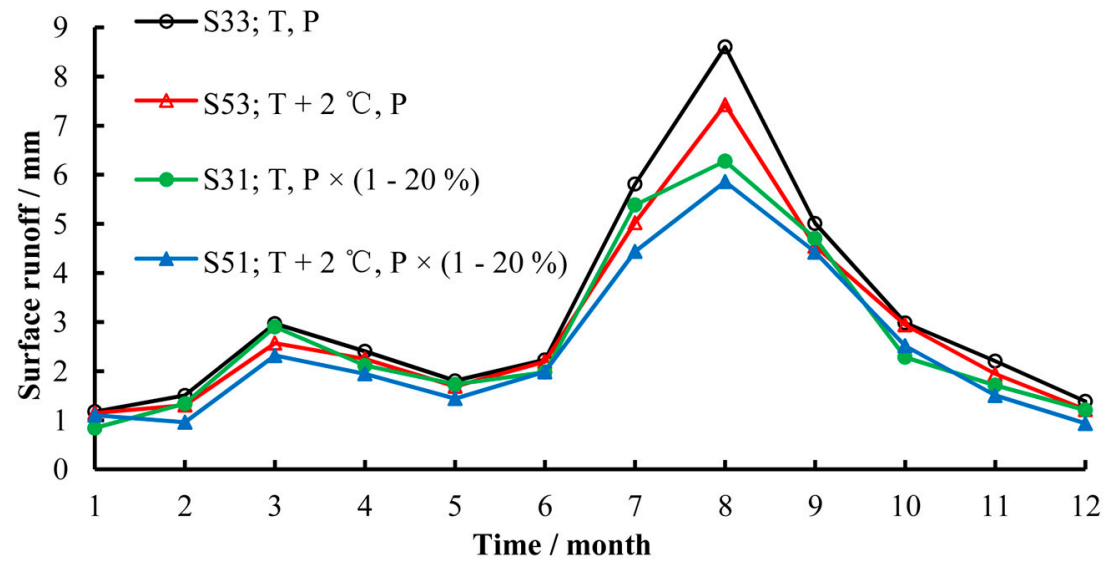

Figure 9. The distribution of monthly surface runoff of S31, S33, S51, and S53 in the Lanhe Watershed.

\subsection{Sensitivity Analysis of Baseflow}

Table 5 presents the annual baseflow obtained by the SWAT model, in accordance with each scenario. The baseflow of S33 was $6463.8 \times 10^{3} \mathrm{~m}^{3}$ (runoff depth $5.67 \mathrm{~mm}$ ), occurring with the annual average precipitation and temperature.

Table 5. Annual baseflow simulated in different scenarios.

\begin{tabular}{ccccccc}
\hline \multirow{2}{*}{ Baseflow } & \multirow{2}{*}{ Temperature } & \multicolumn{5}{c}{ Precipitation } \\
\cline { 3 - 7 } & & $\mathbf{- 2 0 \%}$ & $\mathbf{- 1 0 \%}$ & $\mathbf{0}$ & $\mathbf{1 0 \%}$ & $\mathbf{2 0 \%}$ \\
\hline & $\mathrm{T}-2{ }^{\circ} \mathrm{C}$ & 6076.0 & 6728.8 & 7323.5 & 7885.8 & 8402.9 \\
Volume $\left(10^{3} \mathrm{~m}^{3}\right)$ & $\mathrm{T}-1{ }^{\circ} \mathrm{C}$ & 5668.8 & 6308.7 & 6877.5 & 7426.9 & 7937.5 \\
& $\mathrm{~T}$ & 5306.8 & 5907.9 & 6463.8 & 6987.4 & 7491.5 \\
& $\mathrm{~T}+1{ }^{\circ} \mathrm{C}$ & 5003.0 & 5571.8 & 6127.7 & 6625.4 & 7110.2 \\
& $\mathrm{~T}+2{ }^{\circ} \mathrm{C}$ & 4731.5 & 5268.0 & 5798.0 & 6289.3 & 6754.7 \\
\hline
\end{tabular}

Table 5 and Figure 10 show the differences and rate of change compared with the base S33 scenario. In contrast to the S33 scenario, the minimum relative change of the baseflow decreased by $26.8 \%\left(4731.5 \times 10^{3} \mathrm{~m}^{3}\right.$, S51), while the precipitation decreased by $20 \%$ and the temperature increased by $2{ }^{\circ} \mathrm{C}$. The maximum relative change of the baseflow increased by $30 \%\left(8402.9 \times 10^{3} \mathrm{~m}^{3}\right.$, S15), while the precipitation increased by $20 \%$ and the temperature decreased by $2{ }^{\circ} \mathrm{C}$, respectively.

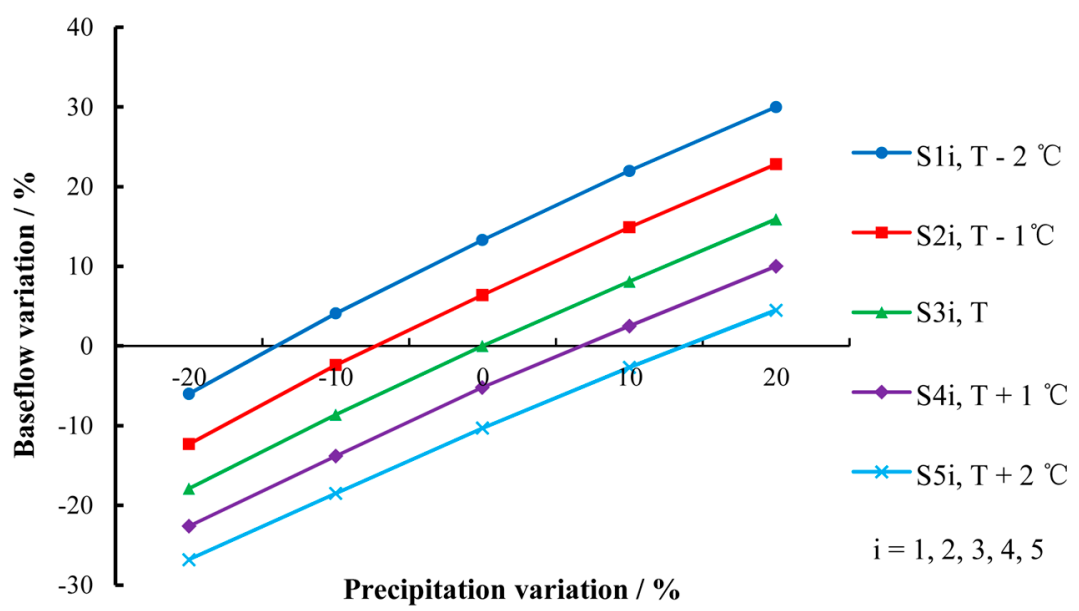

Figure 10. Rate of annual baseflow change of the base and other scenarios. 
For the same precipitation, when the temperature decreases by $1{ }^{\circ} \mathrm{C}$, the baseflow will increase from $362 \times 10^{3} \mathrm{~m}^{3}$ to $465.4 \times 10^{3} \mathrm{~m}^{3}$, by $5.6 \%$ to $7.2 \%$; when the temperature increases by $1{ }^{\circ} \mathrm{C}$, the baseflow will decrease from $271.5 \times 10^{3} \mathrm{~m}^{3}$ to $381.4 \times 10^{3} \mathrm{~m}^{3}$, by $4.2 \%$ to $5.9 \%$.

For the same temperature, the relative changes in baseflow caused by decreasing precipitation are greater than those caused by an increasing precipitation. For instance, when the precipitation change decreases by $10 \%$, the baseflow will decrease from $530 \times 10^{3} \mathrm{~m}^{3}$ to $652.8 \times 10^{3} \mathrm{~m}^{3}$, by $8.2 \%$ to $10.1 \%$; when the precipitation change increases by $10 \%$, the baseflow will increase from $491.3 \times 10^{3} \mathrm{~m}^{3}$ to $562.3 \times 10^{3} \mathrm{~m}^{3}$, by $7.6 \%$ to $8.7 \%$.

Results also show that climate change has more of a contribution to the surface runoff relative to the baseflow.

The monthly baseflow changes are shown in Figure 11. The overall results for each operative scenario (S31, S33, S51, S53) showed that the baseflow yield changes implied significant changes in the post-flood season (October and November), with October showing the largest difference, and slight differences for the ice period (from December to February) and the pre-crop period (from March to May). The baseflow changes appeared to be a time-lag phenomenon with respect to the monthly changes in precipitation. Furthermore, it should also be noted that the contribution of precipitation variability was far greater than that of temperature change.

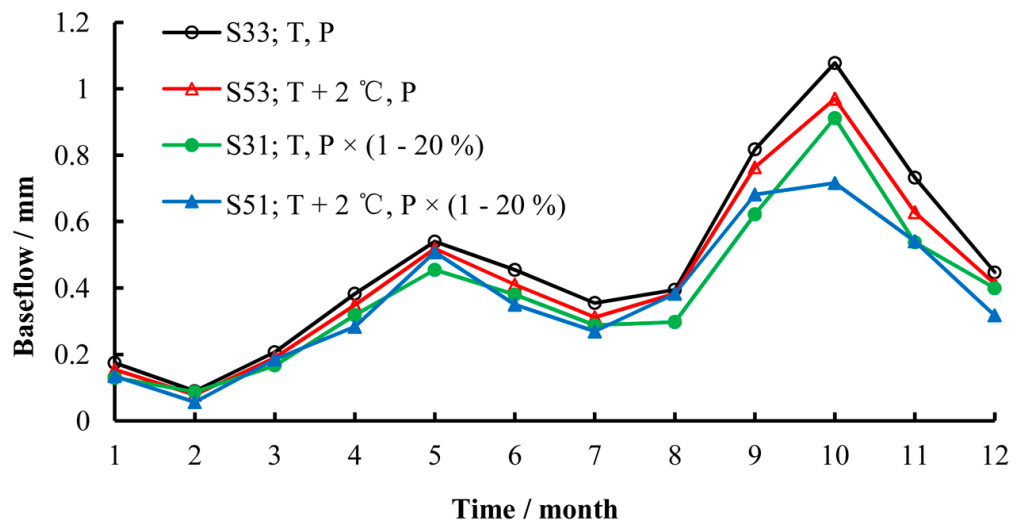

Figure 11. Distribution of monthly baseflow of S33, S53, S31, and S51 in the Lanhe Watershed.

\section{Conclusions}

This study used the SWAT model, which was calibrated and validated with $\mathrm{R}^{2}$, Ens, and PBIAS, and presented the impacts of climate variability on surface runoff and baseflow in the Lanhe Watershed, which has similar hydrological and meteorological characteristics to those of the Loess Plateau. In the calibration period (1967-1996), the annual and monthly $R^{2}$, Ens, and PBIAS were 0.95 and $0.84,0.78$ and 0.72 , and $0.6 \%$ and $-9.1 \%$; in the validation period (1997-2011), the annual and monthly $\mathrm{R}^{2}$, Ens, and PBIAS were 0.90 and $0.78,0.74$ and 0.67 , and $22.1 \%$ and $18.8 \%$. The performance rating of the calibrated and validated SWAT model was better for the prediction variability of surface runoff and baseflow with variability in precipitation and temperature.

The simulated results indicated that the surface runoff was likely to be more affected than baseflow by changes in precipitation and temperature. Additionally, there were distinct variations in seasonal and monthly surface runoff and baseflows. Surface runoff had noticeable changes during the flood season, from June to September, and baseflow had significant variability in the post-flood season, from October to November. Furthermore, the surface runoff and the baseflow had slight variations relative to other periods.

When the precipitation was a constant, the decrease in temperature was more significant than an increase of the surface runoff, and the same results were found for baseflow. Nevertheless, when the temperature was a constant, an increase in the rate of precipitation was more significant than a decrease of the surface runoff; the decrease of precipitation was more remarkable than the increase in baseflow. 
Acknowledgments: This study was funded by the Shanxi Province Science Foundation (No. 2010011030-1) and the Hydrology and Water Resource Survey Administration of Shanxi (No. ZNGZ2015-036), China.

Author Contributions: This research was conducted by all authors. Hua Jin led the project and defined the research themes. Hua Jin and Qiao Zhu designed the methods and modeling and conducted the modeling investigations. Hua Jin and Xuehua Zhao analyzed the data; Yongbo Zhang contributed to the discussion, analyses, and interpretation. All authors have contributed to the revision and approved the manuscript.

Conflicts of Interest: The authors declare no conflict of interest.

\section{References}

1. Palazzoli, I.; Maskey, S.; Uhlenbrook, S.; Nana, E.; Bocchiola, D. Impact of prospective climate change on water resources and crop yields in the Indrawati basin, Nepal. Agric. Syst. 2015, 133, 143-157. [CrossRef]

2. Xu, Y.P.; Zhang, X.J.; Ran, Q.H.; Tian, Y. Impact of climate change on hydrology of upper reaches of Qiantang River Basin, East China. J. Hydrol. 2013, 483, 51-60. [CrossRef]

3. Luo, Y.Z.; Ficklin, D.L.; Liu, X.M.; Zhang, M.H. Assessment of climate change impacts on hydrology and water quality with a watershed modeling approach. Sci. Total Environ. 2013, 450-451, 72-82. [CrossRef] [PubMed]

4. Iensen, I.R.R.; Schultz, G.B.; Santos, I.D. Simulation of hydrosedimentological impacts caused by climate change in the Apucaraninha River watershed, southern Brazil. In Proceedings of the Symposium Held in New Orleans, Louisiana, USA, 11-14 December 2014.

5. Githui, F.; Gitau, W.; Mutua, F.; Bauwens, W. Climate change impact on SWAT simulated streamflow in western Kenya. Int. J. Climatol. 2009, 29, 1823-1834. [CrossRef]

6. Füssel, H.-M. Review and Quantitative Analysis of Indices of Climate Change Exposure, Adaptive Capacity, Sensitivity, and Impacts. 2010. Available online: https:/ /openknowledge.worldbank.org/handle/10986/ 9193 (accessed on 20 July 2015).

7. Karamouz, M.; Goharian, E.; Nazif, S. Reliability Assessment of the water supply systems under uncertain future extreme climate conditions. Earth Interact. 2013, 17, 1-27. [CrossRef]

8. Fowler, H.J.; Kilsby, C.G.; O'Connell, P.E. Modeling the impacts of climatic change and variability on the reliability, resilience, and vulnerability of a water resource system. Water Resour. Res. 2003, 39, 2503-2512. [CrossRef]

9. Liu, Y.; Ren, L.L.; Hong, Y.; Zhu, Y.; Yang, X.L.; Yuan, F.; Jiang, S.H. Sensitivity analysis of standardization procedures in drought indices to varied input data selections. J. Hydrol. 2016, 538, 817-830. [CrossRef]

10. Zhang, L.H.; Yan, J.P.; Liu, L.S. Climate change and drought and flood disasters trend in Shanxi. J. Arid Land Resour. Environ. 2013. (In Chinese) [CrossRef]

11. Ning, T.; Guo, Z.S.; Guo, M.C.; Han, B. Soil water resources use limit in the loess plateau of China. Agric. Sci. 2013, 14, 100-105. [CrossRef]

12. Lv, Z.M.; Li, Z.; Li, J.J.; Dai, R.R. Verifying the applicability of PRECIS-simulated precipitation on the Loess Plateau. Acta Ecol. Sin. 2016, 36. (In Chinese) [CrossRef]

13. Kang, N.; Yang, Y.G.; Li, H.J.; Li, J.C. A study on water environmental carrying capacity of typical mining area in Loess Plateau. Bull. Soil Water Conserv. 2015, 35, 274-280. (In Chinese)

14. Tan, H.B.; Jin, B.; Wang, R.A.; Zhang, Y.D.; Liu, Z.H. Climate change, human activity and water resources issues in loess hilly areas in Pingliang. Water Resour. Prot. 2015, 31, 45-51. (In Chinese)

15. Zeng, S.D.; Xia, J.; She, D.X.; Du, H.; Zhang, L.P. Impacts of climate change on water resources in the Luan River basin in North China. Water Int. 2012, 5, 552-563. [CrossRef]

16. Goharian, E.; Burian, S.; Bardsley, T.; Strong, C. Incorporating Potential Severity into Vulnerability Assessment of Water Supply Systems under Climate Change Conditions. J. Water Resour. Plann. Manag. 2015. [CrossRef]

17. Asefa, T.; Clayton, J.; Adams, A.; Anderson, D. Performance evaluation of a water resources system under varying climatic conditions: Reliability, resilience, vulnerability and beyond. J. Hydrol. 2014, 508, 53-65. [CrossRef]

18. Miller, W.P.; Piechota, T.C.; Gangopadhyay, S.; Pruitt, T. Development of streamflow projections under changing climate conditions over Colorado River basin headwaters. Hydrol. Earth Syst. Sci. 2011, 15, 2145-2164. [CrossRef] 
19. Liu, M. Simulation and Prediction of Climate Change in Eastern China and Assessment of the Response of Hydrology and Water Quality in a Typical Watershed. Ph.D. Thesis, Zhejiang University, Hangzhou, China, April 2015. (In Chinese)

20. York, C.; Goharian, E.; Burian, S. Impacts of large-scale stormwater green infrastructure implementation and climate variability on receiving water response in the Salt Lake City area. Am. J. Environ. Sci. 2015, 11, 278-292. [CrossRef]

21. Maurer, E.P.; Brekke, L.; Pruitt, T.; Duffy, P.B. Fine-resolution climate projections enhance regional climate change impact studies. Eos Trans. Am. Geophys. Union 2007, 88, 504. [CrossRef]

22. Dudula, J.; Randhir, T.O. Modeling the influence of climate change on watershed systems: Adaptation through targeted practices. J. Hydrol. 2016. [CrossRef]

23. Sood, A.; Muthuwatta, L.; McCartney, M.A. SWAT evaluation of the effect of climate change on the hydrology of the Volta River basin. Water Int. 2013, 38, 297-311. [CrossRef]

24. Kirby, J.M.; Mainuddin, M.; Mpelasoka, F.; Ahmad, D.; Palash, W.; Quadir, M.E.; Shah-Newaz, S.M.; Hossain, M.M. The impact of climate change on regional water balances in Bangladesh. Clim. Chang. 2016, 135, 481-491. [CrossRef]

25. Zahabiyoun, B.; Goodarzi, M.R.; Massah Bavani, A.R.; Azamathulla, H.M. Assessment of climate change impact on the Gharesou River Basin using SWAT hydrological model. Clean-Soil Air Water 2013, 41, 601-609. [CrossRef]

26. Krysanova, V.; White, M. Advances in water resources assessment with SWAT-An overview. Hydrol. Sci. J. 2015, 60, 771-783. [CrossRef]

27. Krysanova, V.; Arnold, J.G. Advances in ecohydrological modelling with SWAT-A review. Hydrol. Sci. J. 2008, 53, 939-947. [CrossRef]

28. Gassman, P.W.; Sadeghi, A.M.; Srinivasan, R. Applications of the SWAT modle special section: Overview and insights. J. Environ. Qual. 2014, 43, 1-8. [CrossRef] [PubMed]

29. Li, Z.; Liu, W.Z.; Zhang, X.C.; Zheng, F.L. Impacts of land use change and climate variability on hydrology in an agricultural catchment on the Loess Plateau of China. J. Hydrol. 2009, 377, 35-42. [CrossRef]

30. Han, F.; Ren, L.; Zhang, X.; Li, Z. The WEPP Model application in a small watershed in the Loess Plateau. PLoS ONE 2016, 11, e0148445. [CrossRef] [PubMed]

31. Zhu, Q. Research on Water Resources Responses to Climate Changes in Lanhe Watershed based on SWAT Model. Master's Thesis, Taiyuan University of Technology, Taiyuan, China, June 2013. (In Chinese)

32. Gao, Z.Q. GM(1,2) time-lag model of mid-long term runoff forecasting on Lanhe River. J. Taiyuan Univ. Technol. 2006, 37, 71-73. (In Chinese)

33. Liu, Y. Analysis on the hydrological characteristics of Lanhe watershed. Sci-Tech Inf. Dev. Econ. 2008, 18, 135-136. (In Chinese)

34. Neitsch, S.L.; Arnold, J.G.; Kiniry, J.R.; Srinivasan, R.; Williams, J.R. Soil and Water Assessment Tool User's Manual. Available online: http://swat.tamu.edu/media/1294/swatuserman.pdf (accessed on 3 June 2014).

35. Neitsch, S.L.; Arnold, J.G.; Kiniry, J.T.; Williams, J.R. Soil and Water Assessment Tool. Theoretical Documentation Version 2009. Available online: http://swat.tamu.edu/media/99192/swat2009-theory.pdf (accessed on 3 June 2014).

36. Moriasi, D.N.; Wilson, B.N.; Douglas-Mankin, K.R.; Arnold, J.G.; Gowda, P.H. Hydrologic and water quality models: Use, Calibration, and Validation. Trans. ASABE 2012, 55, 1241-1247. [CrossRef]

37. Arnold, J.G.; Kiniry, J.R.; Srinivasan, R.; Williams, J.R.; Haney, E.B.; Neitsch, S.L. Soil and Water Assessment Tool Input/Output Documentation. Available online: http://swat.tamu.edu/media/69296/SWAT-IODocumentation-2012.pdf (accessed on 3 June 2014).

38. Moriasi, D.N.; Gitau, M.W.; Pai, N.; Daggupati, P. Hydrologic and water quality models: Performance measures and evaluation criteria. Trans. ASABE 2015, 58, 1763-1785.

39. Malagó, A.; Venohr, M.; Gericke, A.; Vigiak, O.; Bouraoui, F.; Grizzetti, B.; Kovacs, A. Modelling nutrient pollution in the Danube River Basin: A comparative study of SWAT, MONERIS and GREEN models. Publ. Off. Eur. Union 2015. [CrossRef]

40. Gassman, P.W.; Sadeghi, A.M.; Srinivasan, R. Applications of the SWAT model special section: Overview and insights. J. Environ. Qual. 2014, 43, 1-8. [CrossRef] [PubMed]

41. Qiao, L.; Zou, C.B.; Will, R.E.; Stebler, E. Calibration of SWAT model for woody plant encroachment using paired experimental watershed data. J. Hydrol. 2015, 523, 231-239. [CrossRef] 
42. Bouslihim, Y.; Kacimi, I.; Brirhet, H.; Khatati, M.; Rochdi, A.; Pazza, N.E.A.; Miftah, A.; Yaslo, Z. Hydrologic modeling using SWAT and GIS, application to subwatershed Bab-Merzouka (Sebou, Morocco). J. Geogr. Inf. Syst. 2016, 8, 20-27. [CrossRef]

43. Arnold, J.G.; Allen, P.M.; Bernhardt, G. A comprehensive surface groundwater flow model. J. Hydrol. 1993, 142, 47-69. [CrossRef]

44. Vrochidou, A.-E.K.; Tsanis, I.K.; Grillakis, M.G.; Koutroulis, A.G. The impact of climate change on hydrometeorological droughts at a basin scale. J. Hydrol. 2013, 476, 290-301. [CrossRef]

45. Koutroulis, A.G.; Tsanis, I.K.; Daliakopoulos, I.N.; Jacob, D. Impact of climate change on water resources status: A case study for Crete Island, Greece. J. Hydrol. 2013, 479, 146-158. [CrossRef]

46. Liuzzo, L.; Noto, L.V.; Arnone, E.; Caracciolo, D.; Loggia, G.L. Modification in water resources availability under climate changes: A case study in a Sicilian basin. Water Resour. Manag. 2015, 29, 1117-1135. [CrossRef]

47. Neupane, R.P.; White, J.D.; Alexander, S.E. Projected hydrologic changes in monsoon-dominated Himalaya Mountain basins with changing climate and deforestation. J. Hydrol. 2015, 525, 216-230. [CrossRef]

48. Kannan, N.; White, S.M.; Worrall, F.; Whelan, M.J. Sensitivity analysis and identification of the best evapotranspiration and runoff options for hydrological modeling in SWAT-2000. J. Hydrol. 2007, 332, 456-466. [CrossRef]

49. Arnold, J.G.; Moriasi, D.N.; Gassman, P.W.; Abbaspour, K.C.; White, M.J.; Srinivasan, R.; Santhi, C.; Harmel, R.D.; van Griensven, A.; van Liew, M.W.; et al. SWAT: Model use, calibration, and validation. Trans. ASABE 2012, 55, 1494-1508. [CrossRef]

50. Jung, Y.W.; Oh, D.; Kim, M.; Park, J.W. Calibration of LEACHN model using LH-OAT sensitivity analysis. Nutr. Cycl. Agroecosyst. 2010, 87, 261-275. [CrossRef]

51. Song, W.X.; Jiang, S.H.; Yang, C.S.; Wang, L.M. Impact of SCE-UA and SCEM-UA on improved HYMOD model. Water Resour. Power 2013, 31, 17-20. (In Chinese)

52. Setegn, S.G.; Melesse, A.M.; Haiduk, A.; Webber, D.; Wang, X.; McClain, M.E. Modeling hydrological variability of fresh water resources in the Rio Cobre watershed, Jamaica. Catena 2014, 120, 81-90. [CrossRef]

53. Van Liew, M.W.; Veith, T.L.; Bosch, D.D.; Arnold, J.G. Suitability of SWAT for the conservation effects assessment project: A comparison on USDA-ARS experimental watersheds. J. Hydrol. Eng. 2007, 12, 173-189. [CrossRef]

54. Gan, R.; Luo, Y.; Zuo, Q.T.; Sun, L. Effects of projected climate change on the glacier and runoff generation in the Naryn River Basin, Central Asia. J. Hydrol. 2015, 523, 240-251. [CrossRef]

55. Malagò, A.; Pagliero, L.; Bouraoui, F.; Franchini, M. Comparing calibrated parameter sets of the SWAT model for the Scandinavian and Iberian peninsulas. Hydrol. Sci. J. 2015, 60, 949-967. [CrossRef]

56. Moriasi, D.N.; Arnold, J.G.; Van liew, M.W.; Bingner, R.L.; Harmel, R.D.; Veith, T.L. Model evaluation guidelines for systematic quantification of accuracy in watershed simulations. Trans. ASABE 2007, 50, 885-900. [CrossRef]

57. Jankowfsky, S.; Branger, F.; Braud, I.; Rodriguez, F.; Debionne, S.; Viallet, P. Assessing anthropogenic influence on the hydrology of small peri-urban catchments: Development of the object-oriented PUMMA model by integrating urban and rural hydrological models. J. Hydrol. 2014, 517, 1056-1071. [CrossRef]

58. Loliyana, V.D.; Patel, P.L. Trend analysis of climatic variables and their impact on stream flow using NAM model. In Proceedings of the 36th IAHR World Congress, Hague, The Netherlands, 28 June-3 July 2015.

59. Liu, Z.P.; Wang, Y.Q.; Shao, M.G.; Jia, X.X.; Li, X.L. Spatiotemporal analysis of multiscalar drought characteristics across the Loess Plateau of China. J. Hydrol. 2016, 534, 281-299. [CrossRef]

60. Du, S.Q.; Gu, H.H.; Wen, J.H.; Chen, K.; Rompaey, A.V. Detecting Flood Variations in Shanghai over 1949-2009 with Mann-Kendall Tests and a Newspaper-Based Database. Water 2015, 7, 1808-1824. [CrossRef]

61. Chatterjee, S.; Bisai, D.; Khan, A. Detection of approximate potential trend turning points in temperature time series (1941-2010) for Asansol Weather Observation Station, West Bengal, India. Atmos. Clim. Sci. 2014, 4, 64-69. [CrossRef]

(C) 2016 by the authors; licensee MDPI, Basel, Switzerland. This article is an open access article distributed under the terms and conditions of the Creative Commons Attribution (CC-BY) license (http:/ / creativecommons.org/licenses/by/4.0/). 